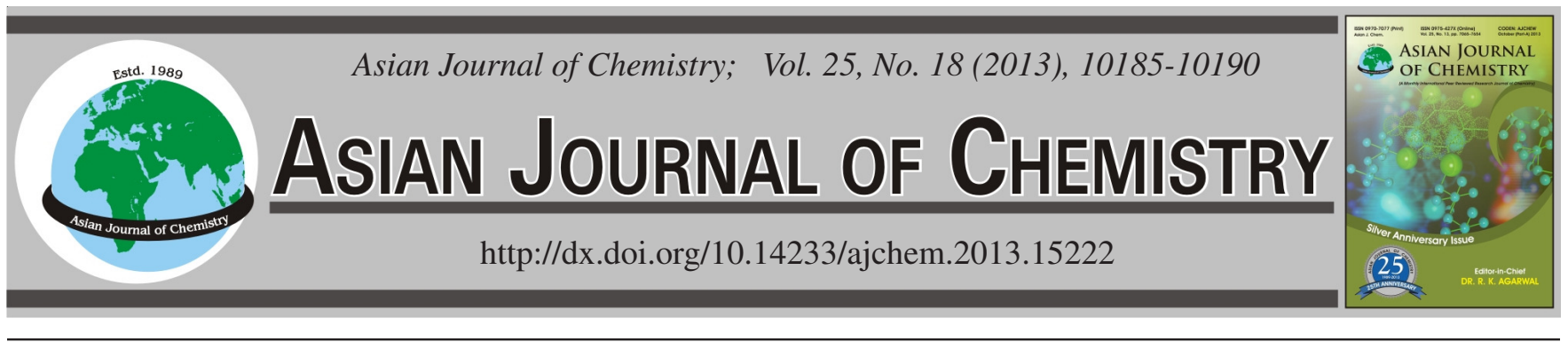

\title{
Evaluation of Chemical and Microbiological Characteristics and Fatty Acid Profiles of Butter Samples Collected from the Black Sea Region of Turkey
}

\author{
Muhammet Dervisoglu ${ }^{1, *}$, Osman Gul ${ }^{2}$, Dilek Guvenc ${ }^{3}$, Fehmi Yazici $^{1}$, Enes Atmaca ${ }^{3}$ and Abdurrahman Aksoy ${ }^{3}$
}

\begin{abstract}
${ }^{1}$ Department of Food Engineering, Engineering Faculty, Ondokuz Mayis University, Samsun 55139, Turkey
${ }^{2}$ Program of Food Technology, Yesilyurt Demir-Çelik Vocational School, Ondokuz Mayis University, Samsun 55600, Turkey

${ }^{3}$ Department of Pharmacology and Toxicology, Faculty of Veterinary Medicine, Ondokuz Mayis University, Samsun 55139, Turkey
\end{abstract}

*Corresponding author: E-mail: mderviso@omu.edu.tr

(Received: 28 January 2013;

Accepted: 11 November 2013)

AJC-14363

The physico-chemical and microbiological characteristics and fatty acid composition of butter samples produced in the Black sea region
of Turkey were analyzed. The mean percentages of total solids, non-fat solids and fat were $85.36,2.71$ and $82.64 \%$, respectively; the $\mathrm{pH}$
and titratable acidity, 4.64 and $0.55 \%$, respectively; the salt and ash contents, 0.51 and $0.81 \%$, respectively and the peroxide content, 1.19
meq $\mathrm{O}_{2} / \mathrm{kg}$ fat. The average colour values of $\mathrm{L}$, a and $\mathrm{b}$ for the butter samples were $78.49,-1.3$ and 24.74 , respectively. The mean counts
of aerobic mesophilic bacteria, enterococci, lactic acid bacteria, yeast and mould, coliform and Escherichia coli organisms in the butter
samples were $6.01,5.81,4.22,5.14,2.76$ and $2.29 \mathrm{log} \mathrm{CFU} / \mathrm{g}$, respectively. Staphylococcus aureus was not detected in any of the
samples. The predominant fatty acids in the butter samples were palmitic acid $(33.72 \%)$, oleic acid $(20.79 \%)$, myristic acid $(11.17 \%)$
and stearic acid (10.47\%).

\section{INTRODUCTION}

Butter is produced from cream or yoghurt in dairy factories and on farms in Turkey; the traditional butter made from yoghurt is called 'Yayik butter' and has been produced for centuries ${ }^{1}$. Factory-produced butter is generally made from cream, packaged in aluminium foil, plastic or paper and then stored at between 4 and $18{ }^{\circ} \mathrm{C}{ }^{2}$. According to the Turkish Butter Standards, butter is described as "a dairy product obtained from cream or yoghurt" and as "having a characteristic flavour, odour and consistency" . The components of butter are legislated in a number of countries and the product usually includes 80-84\% milk fat, 15.3-15.9\% water, $1 \%$ non-fat dry matter and $0.03-1.8 \%$ salt $^{4}$. To produce butter from cream, the cream is first pasteurized at $90-95^{\circ} \mathrm{C}$ for 15 $20 \mathrm{~min}$, followed by cooling to $15-20^{\circ} \mathrm{C}$. The cream is then churned for ca. $60-70 \mathrm{~min}$, at which time the fat globules coalesce. The buttermilk is removed and the butter is washed once or twice before the slabs are wrapped ${ }^{2}$.

In the Black sea region, milk products are mainly produced in small factories that generally use simple methods and with little regard to the raw material source, quality and hygiene history of milk used. For these reasons, the composition and hygiene qualities of dairy products are not guaranteed ${ }^{5}$.
Many studies have investigated the microbial content and chemical qualities of milk and milk products produced in Turkey. However, there is no published information about the chemical and microbiological quality of butters produced in the Black sea region of Turkey. In the present study, we therefore aimed to determine the chemical and microbiological characteristics and fatty acid content of butter samples collected from that region during two production periods and three sub-regions and to discuss the legal stipulations in Turkey.

\section{EXPERIMENTAL}

In 2009 and 2010, a total of 88 samples of butter manufactured by 44 different firms were obtained randomly from markets in the East, Middle and West sub-regions of the Black sea region of Turkey. The butter was produced in OctoberNovember 2009 (first period) or May-June 2010 (second period). The samples ( $1 \mathrm{~kg}$ ) were transported to the laboratory in an insulated container at $4{ }^{\circ} \mathrm{C}$ and analyzed upon arrival.

Chemical analysis: The total solids content of the butter samples was determined by heating at $103 \pm 1^{\circ} \mathrm{C}$ to constant weight ${ }^{6}$ and the percentage of non-fat solids was calculated with the method of Van Gulik ${ }^{7}$. Titratable acidity and salt and ash content were determined according to the methods described by Bradley et al. ${ }^{8}$. The $\mathrm{pH}$ was measured using a 
$\mathrm{pH}$ meter (model pH 510, Eutech Instruments, Singapore) equipped with a probe for solids (Sensorex, Garden Grove, CA, USA) and according to the methods of the Association of Official Analytical Chemists ${ }^{9}$.

Colour measurement: Colour analyses on the butter samples were conducted with a colourimeter (Chroma Meter CR-300; Minolta, Osaka, Japan) to measure the Hunter L, a and $b$ values. Measurements were performed on subsamples taken from 5 separate areas of the butter sample.

Microbiological analysis: Ten gram butter samples were dispersed in $90 \mathrm{~mL}$ of sterile $0.85 \%(\mathrm{w} / \mathrm{v}) \mathrm{NaCl}$ solution at $45^{\circ} \mathrm{C}$ in a Stomacher laboratory blender (Smasher; AES Chemunex, Bruz, France). Ten-fold dilutions ranging from $10^{-1}-10^{-8}$ were prepared and incubated under the following conditions to determine the microbial contents of the samples: for total aerobic mesophilic bacterial growth, plate count agar at $30{ }^{\circ} \mathrm{C}$ for $72 \mathrm{~h}^{10}$; for lactic acid bacteria (LAB), MRS agar (adjusted to $\mathrm{pH} 5.4$ with acetic acid) at $30^{\circ} \mathrm{C}$ for $72 \mathrm{~h}^{11}$; for coliform bacteria, violet-red bile agar at $37^{\circ} \mathrm{C}$ for $24 \mathrm{~h}^{12}$; for Escherichia coli, chromocult TBX agar at $44^{\circ} \mathrm{C}$ for $24 \mathrm{~h}^{13}$; for Staphylococcus aureus, Baird-Parker agar (incorporating $5 \%$ egg yolk tellurite emulsion) at $37^{\circ} \mathrm{C}$ for $24 \mathrm{~h}^{14}$; for yeasts and moulds, yeast glucose chloramphenicol (YGC) agar at $25^{\circ} \mathrm{C}$ for 5 days ${ }^{15}$ and for enterococci, kanamycin esculin agar at $37^{\circ} \mathrm{C}$ for $48 \mathrm{~h}^{16}$.

Fatty acid analysis: The butter samples were warmed to $37^{\circ} \mathrm{C}$ immediately prior to analysis, then vortexed vigorously to achieve sample uniformity. The method described by Zeppa et $a l .{ }^{17}$ was used for the analysis of fatty acid methyl esters (FAMEs). For transesterification of the lipids in $0.4 \mathrm{~mL}$ of butter, $4 \mathrm{~mL}$ of isooctane was added to the sample and shaken slowly for $0.5 \mathrm{~min}$. The samples were kept in the dark for $6 \mathrm{~min} ; 2 \mathrm{~mL}$ of $2 \mathrm{~N}$ potassium hydroxide in methanol was then added and neutralized with $1 \mathrm{~N} \mathrm{HCl}$. The upper layer was removed and analyzed with a Shimadzu gas chromatography unit with a flame ionization detector (Model GC-2010, Shimadzu Corporation, Kyoto, Japan). The fatty acids were separated in a capillary column DB $23(60 \mathrm{~m} \times 0.25 \mathrm{~mm}$ i.d., $0.25 \mu \mathrm{m})(\mathrm{J} \& \mathrm{~W}$ Scientific, Folson, CA, USA) with an injected volume of $1 \mu \mathrm{L}$. The operating conditions and procedures were as follows; injector port and detector temperatures were held at 270 and $280^{\circ} \mathrm{C}$, respectively. The carrier gas was helium at a pressure of $150 \mathrm{kPa}$; the split ratio was $10^{-2}$; the column temperature was maintained at $130^{\circ} \mathrm{C}$ for $2 \mathrm{~min}$, then ramped at $6.5^{\circ} \mathrm{C} / \mathrm{min}$ to $170{ }^{\circ} \mathrm{C}$ and at $2.75^{\circ} \mathrm{C} / \mathrm{min}$ to $215^{\circ} \mathrm{C}$, held at $215^{\circ} \mathrm{C}$ for $6 \mathrm{~min}$, raised again to $240{ }^{\circ} \mathrm{C}$ at $40{ }^{\circ} \mathrm{C} / \mathrm{min}$ and finally held at $240{ }^{\circ} \mathrm{C}$ for $10 \mathrm{~min}$. Fatty acid methyl esters were identified by comparison of their retention times with those of standard references (Supelco 37 Component FAME Mixture, Bellefonte, PA, USA) and results were expressed as w/w $(\%)$ total fatty acid.

Statistical analysis: Statistical analyses were performed using SPSS version 17.0 software (SPSS Inc. Chicago, Illinois); the effects of geographic region and sampling period were analysed with ANOVA and Duncan's test for multiple comparisons $(\alpha=0.05)$.

\section{RESULTS AND DISCUSSION}

Chemical characteristics: The results of the chemical analysis of the 88 butter samples are provided in Table- 1 . The mean values of total solids, non-fat solids, fat, titratable acidity, $\mathrm{pH}$, salt, ash and peroxide were $85.36,2.71,82.64$, $0.55,4.64,0.51,0.81 \%$ and $1.19 \mathrm{meq} \mathrm{O}_{2} / \mathrm{kg}$ of fat, respectively. According to the Turkish Food Codex and TS 1331 Butter Standards, butter must contain minimums of $80 \%$ milk fat and $84 \%$ total solids and maximums of $2 \%$ non-fat solids and $5 \mathrm{meq} \mathrm{O}_{2} / \mathrm{kg} \mathrm{fat}^{3,18}$. In this study, 27 of 88 samples (30.68\%) did not comply with the TS 1331 Butter Standards for total solids content, 17 of $88(19.32 \%)$ did not comply for fat content and 59 of $88(67.05 \%)$ did not comply for non-fat solids content. However, all 88 samples satisfied the criteria for peroxide consumption. Altun et al. ${ }^{4}$ found that 80,90 and $70 \%$ of butter samples were non-compliant with the aforementioned butter standards for moisture content, non-fat solids and fat content, respectively. The mean titratable acidity values in the present study were higher than these of Sagdic et al. ${ }^{1}$. However, the mean $\mathrm{pH}$ values were similar to those reported in earlier studies ${ }^{1,10}$. The mean salt content was similar to the value reported by Sagdic et al. ${ }^{1}$ but lower than these of Mourad and Nour-Eddine ${ }^{19}$. In addition, the mean ash percentage in present study was lower than that reported by SametBali et al. ${ }^{10}$.

TABLE-1

PHYSICOCHEMICAL CHARACTERISTICS AND THE L-, a-, b-VALUES OF BUTTER SAMPLES COLLECTED FROM THE EAST, MIDDLE AND WEST BLACK SEA REGIONS OF TURKEY IN OCTOBER-NOVEMBER 2009 AND MAY-JUNE 2010

\begin{tabular}{|c|c|c|c|c|c|c|}
\hline \multirow{2}{*}{ Variable } & \multicolumn{3}{|c|}{ Region* } & \multicolumn{2}{|c|}{ Period** } & \multirow{2}{*}{ Average } \\
\hline & East & Middle & West & First & Second & \\
\hline Total solids (\%) & $84.13 \pm 4.39^{\text {bc }}$ & $86.78 \pm 3.18^{\mathrm{a}}$ & $85.86 \pm 3.38^{\mathrm{ab}}$ & $84.85 \pm 3.48^{\mathrm{A}}$ & $85.86 \pm 4.21^{\mathrm{A}}$ & $85.36 \pm 3.87$ \\
\hline Non-fat solids (\%) & $2.74 \pm 1.2^{\mathrm{a}}$ & $3.01 \pm 1.32^{\mathrm{a}}$ & $2.57 \pm 1.09^{\mathrm{a}}$ & $2.46 \pm 1.12^{\mathrm{B}}$ & $2.97 \pm 1.18^{\mathrm{A}}$ & $2.71 \pm 1.17$ \\
\hline Fat $(\%)$ & $81.39 \pm 3.92^{b}$ & $83.77 \pm 2.46^{\mathrm{a}}$ & $83.29 \pm 2.95^{\mathrm{a}}$ & $82.39 \pm 3.23^{\mathrm{A}}$ & $82.89 \pm 3.59^{\mathrm{A}}$ & $82.64 \pm 3.4$ \\
\hline $\mathrm{TA}(\%)$ & $0.57 \pm 0.33^{\mathrm{a}}$ & $0.39 \pm 0.24^{\mathrm{b}}$ & $0.6 \pm 0.28^{\mathrm{a}}$ & $0.66 \pm 0.36^{\mathrm{A}}$ & $0.44 \pm 0.19^{\mathrm{B}}$ & $0.55 \pm 0.3$ \\
\hline $\mathrm{pH}$ & $4.57 \pm 0.32^{\mathrm{a}}$ & $4.8 \pm 4.78^{\mathrm{a}}$ & $4.62 \pm 0.47^{\mathrm{a}}$ & $4.41 \pm 0.35^{\mathrm{A}}$ & $4.86 \pm 0.36^{\mathrm{A}}$ & $4.64 \pm 0.42$ \\
\hline Salt (\%) & $0.67 \pm 0.31^{\mathrm{a}}$ & $0.45 \pm 0.32^{\mathrm{b}}$ & $0.4 \pm 0.23^{\mathrm{b}}$ & $0.54 \pm 0.29^{\mathrm{A}}$ & $0.48 \pm 0.32^{\mathrm{A}}$ & $0.51 \pm 0.31$ \\
\hline Ash (\%) & $0.95 \pm 0.43^{\mathrm{ab}}$ & $0.68 \pm 0.39^{\mathrm{bc}}$ & $0.74 \pm 0.47^{b}$ & $0.88 \pm 0.47^{\mathrm{A}}$ & $0.75 \pm 0.42^{\mathrm{A}}$ & $0.81 \pm 0.45$ \\
\hline Peroxide (meq $\mathrm{O}_{2} / \mathrm{kg}$ fat) & $1.32 \pm 0.99^{\mathrm{a}}$ & $1.26 \pm 0.91^{\mathrm{a}}$ & $1.05 \pm 0.56^{\mathrm{a}}$ & $1.16 \pm 0.69^{\mathrm{A}}$ & $1.24 \pm 0.93^{\mathrm{A}}$ & $1.19 \pm 0.82$ \\
\hline L- & $77.62 \pm 1.6^{\mathrm{b}}$ & $79.33 \pm 2.06^{\mathrm{a}}$ & $78.92 \pm 2.01^{\mathrm{a}}$ & $78.44 \pm 1.92^{\mathrm{A}}$ & $78.54 \pm 2.07^{\mathrm{A}}$ & $78.49 \pm 1.98$ \\
\hline$a-$ & $-0.79 \pm 0.96^{\mathrm{a}}$ & $-1.81 \pm 0.53^{\mathrm{b}}$ & $-1.53 \pm 0.68^{b}$ & $-1.3 \pm 0.88^{\mathrm{A}}$ & $-1.29 \pm 0.88^{\mathrm{A}}$ & $-1.3 \pm 0.88$ \\
\hline $\mathrm{b}-$ & $26.53 \pm 5.45^{b}$ & $23.61 \pm 3.54^{\mathrm{a}}$ & $23.62 \pm 4.49^{\mathrm{a}}$ & $24.76 \pm 4.91^{\mathrm{A}}$ & $24.73 \pm 4.95^{\mathrm{A}}$ & $24.74 \pm 4.91$ \\
\hline
\end{tabular}

Values are expressed as mean \pm standard deviation. ${ }^{*}$ a-c and ${ }^{* *}$ A-B: means with different letters in a row (ie within the same category) are significantly different $(p<0.05)$. 
The butter production period had a significant effect only on the titratable acidity and $\mathrm{pH}$ values $(p<0.05)$. The total solids and fat content of the butter samples produced in the Middle Black sea region were significantly higher than samples produced in the East and West regions $(p<0.05)$. However, the salt and ash contents and titratable acidity were highest in the West Black Sea region $(p<0.05)$.

Colour properties: On the Hunter colour scale, L, a and $\mathrm{b}$ values represent light to dark, red (+a) to green $(-\mathrm{a})$ and yellow $(+b)$ to blue $(-b)$, respectively. The average values for the butter samples analyzed were 78.49 for L, -1.3 for a and 24.74 for $b$ (Table-1). The colour properties of the butter samples were not affected by the production period $(p>0.05)$, but did vary with the production region. Samples from the East Black sea region were darker, redder and yellower than samples from the other regions $(p<0.05)$. One possible explanation for this finding is that the animal feeds in that region may contain higher levels of $\beta$-carotene. In most cases, when appearance factors (especially colour) cause selection or rejection impulses for butters, their potential interrelationships with other basic properties (e.g. flavour) cannot be ignored. It is well documented that certain colourants infer a relationship between the product and a most probable source of origin, irrespective of the actual flavour ${ }^{20}$.

Microbiological properties: The results of the microbiological analysis of the butter samples are shown in Table-2. The mean combined yeast and mould count for the samples was $5.14 \log$ CFU/g. Seventy eight of 88 samples were above the critical limit of $4 \log \mathrm{CFU} / \mathrm{g}$ for yeast and mould content set by the Turkish Food Codex Microbiological Criteria Notification $^{21}$. By comparison, Karagozlu and Ergonul ${ }^{22}$ investigated 45 butter samples collected from Manisa in Turkey and found that only 3 of the samples were under the critical limit for yeast and mould content.

The presence of coliform bacteria in food products is a result of insufficient heat treatment or recontamination after heat treatment ${ }^{23}$. In our study, 44 of 88 samples (50\%) were contaminated with coliform bacteria. The TS 1331 Butter Standard $^{3}$ set the acceptable limit for coliform bacteria at $1 \mathrm{log}$ CFU/g for pasteurized butter; in our study, only $4.5 \%$ of samples were below the limit. Gun ${ }^{24}$ reported coliform bacteria counts of between 1.3 and $2.62 \mathrm{log}$ CFU/g in Karin butter samples, which is similar result to that of our study. However, Sagdic et $a l .{ }^{25}$ did not detect coliform bacteria in their study of Yayik butter.
The E. coli content of food products is considered a reliable indicator of faecal contamination and indicates the possible presence of enteropathogenic and/or toxigenic microorganisms ${ }^{26}$. The Turkish Food Codex states that butter should contain no $E$. $\operatorname{coli}^{21}$. We found that 23 of the 88 butter samples in our study were contaminated with E. coli. By comparison, Karagozlu and Ergonul ${ }^{22}$ reported that all their butter samples were contaminated with $E$. coli.

The Turkish Food Codex and TS 1331 Butter Standard set no restrictions for the total aerobic mesophilic bacteria counts in butter. However, butter is classified according to its total aerobic mesophilic bacteria content as very good quality ( $<6 \log \mathrm{CFU} / \mathrm{g}$ ), good quality (6-6.3 log CFU/g) and poor quality ( $>6.3 \log \mathrm{CFU} / \mathrm{g})^{23}$. According to that classification, $51.14,18.18$ and $30.63 \%$ of the butter samples in our study were categorised as very good, good and poor quality, respectively.

Staphylococcus aureus is an important cause of mastitis and is often found in milk products that are insufficiently heat treated $^{23}$. According to the Turkish Food Codex, the $S$. aureus count must not exceed $2 \log \mathrm{CFU} / \mathrm{g}^{21}$. However, we did not detect it in our samples. Similarly, Karagozlu and Ergonul ${ }^{22}$ did not detect $S$. aureus in any of their butter samples from Manisa city.

Enterococci play a major role in the butter ripening process and development of the characteristic butter aromas ${ }^{19}$. However, Giraffa ${ }^{27}$ stated that the presence of enterococci in milk products may be due to inadequate sanitary conditions during production. We detected enterococci in all butter samples, with a mean level of $4.22 \log \mathrm{CFU} / \mathrm{g}$.

Lactic acid bacteria (LAB) plays an important role in the development of the flavour characteristics of dairy products. The production of diacetyl and acetaldehyde and conversion of lactose to lactic acid by the LAB are their main contributions to the flavour of cultured milk and milk products ${ }^{28}$. The current study reports a mean LAB count in the butter samples of $5.81 \log \mathrm{CFU} / \mathrm{g}$, which is higher than that reported by Sagdic et $a l .^{25}$.

We noted regional variations in the microbial content of the samples; the total aerobic mesophilic bacteria counts were highest in the West Black sea region but coliform and E. coli counts were highest in the Middle Black sea region $(p<0.05)$. In this study, there was a negative correlation between these microorganisms and titratable acidity. Many authors have indicated that survival and growth of these microorganisms

TABLE-2

SOME MICROBIOLOGICAL CHARACTERISTICS OF BUTTER SAMPLES COLLECTED FROM THE EAST, MIDDLE AND WEST BLACK SEA REGIONS OF TURKEY IN OCTOBER-NOVEMBER 2009 AND MAY-JUNE 2010 PRESENTED AS log CFU/g

\begin{tabular}{|c|c|c|c|c|c|c|}
\hline \multirow{2}{*}{ Microorganisms } & \multicolumn{3}{|c|}{ Region* } & \multicolumn{2}{|c|}{ Period** } & \multirow{2}{*}{ Average } \\
\hline & East & Middle & West & First & Second & \\
\hline Yeast-Mould & $5.02 \pm 0.91^{\mathrm{a}}$ & $4.94 \pm 0.66^{a}$ & $5.34 \pm 0.86^{\mathrm{a}}$ & $5.34 \pm 0.89^{A}$ & $4.95 \pm 0.77^{\mathrm{A}}$ & $5.14 \pm 0.86$ \\
\hline Enterecocci & $4.18 \pm 1.03^{\mathrm{a}}$ & $3.88 \pm 0.94^{\mathrm{a}}$ & $4.22 \pm 0.98^{\mathrm{a}}$ & $3.82 \pm 0.92^{\mathrm{B}}$ & $4.62 \pm 0.88^{\mathrm{A}}$ & $4.22 \pm 0.98$ \\
\hline AMB & $5.76 \pm 0.57^{\mathrm{bc}}$ & $6.03 \pm 0.62^{b}$ & $6.22 \pm 0.7^{\mathrm{ba}}$ & $5.82 \pm 0.55^{\mathrm{B}}$ & $6.19 \pm 0.71^{\mathrm{A}}$ & $6.01 \pm 0.66$ \\
\hline LAB & $5.67 \pm 0.56^{\mathrm{a}}$ & $5.66 \pm 0.89^{\mathrm{a}}$ & $6.01 \pm 0.61^{\mathrm{a}}$ & $5.68 \pm 0.64^{\mathrm{A}}$ & $5.95 \pm 0.67^{\mathrm{A}}$ & $5.81 \pm 0.67$ \\
\hline Coliform & $2.36 \pm 0.88^{b}$ & $3.41 \pm 0.46^{\mathrm{a}}$ & $2.74 \pm 0.98^{b}$ & $2.74 \pm 1.11^{\mathrm{A}}$ & $2.78 \pm 0.81^{\mathrm{A}}$ & $2.76 \pm 0.93$ \\
\hline E. coli & $1.68 \pm 0.66^{b c}$ & $2.62 \pm 0.93^{\mathrm{ab}}$ & $2.44 \pm 0.7^{\mathrm{b}}$ & $2.17 \pm 1.03^{\mathrm{A}}$ & $2.35 \pm 0.74^{\mathrm{A}}$ & $2.29 \pm 0.82$ \\
\hline
\end{tabular}

$S$. aureus was not detected in any samples. Values are expressed as mean \pm standard deviation. Means were calculated for samples where coliform bacteria and $E$. coli were detected. ${ }^{*}$ a-c and ${ }^{* *} \mathrm{~A}-\mathrm{B}$ : means with different letters in a row (i.e. within the same category) are significantly different $(p$ $<0.05)$. 
may be inhibited by lactic acid production ${ }^{29,30}$. Additionally, in present study, the yeast and mould counts were highest in samples from the first production period, whereas enterococci counts were the highest in the second period $(p<0.05)$.

Fatty acid composition: Chromatograms of fatty acids obtained from standards and butter samples are shown in Fig. 1 and the fatty acid compositions of butter samples are shown in Table-3. The mean saturated fatty acid (SFA) percentage of the butter samples was $73.63 \%$ and the predominant ones were palmitic acid (C16:0) (32.15\%), myristic acid (C14:0) $(12.71 \%)$, stearic acid (C18:0) (12.11\%) and lauric acid (C12:0) (4.53\%). Sagdic et al. $^{25}$ reported a lower saturated fatty acid content of butter from cows' milk $(67.06 \%)$ than present study. Their palmitic acid, myristic acid, stearic acid and lauric acid contents were 33.72, 11.17, 10.47 and $2.4 \%$, respectively. Palmitic acid, myristic acid and lauric acid elevate the serum cholesterol level while stearic acid does not influence $\mathrm{it}^{31}$. In present study, the amounts of some other important saturated fatty acids, namely butyric acid ( $\mathrm{C} 4: 0)$, caproic acid (C6:0), caprylic acid (C8:0) and capric acid (C10:0), were 2.16, $2.04,1.4$ and $3.14 \%$, respectively. These results approximate those reported by Ledoux et al. ${ }^{32}$. In contrast, the butyric, caproic, caprylic and capric acid contents of Turkish butter obtained from cows' milk were 1.83, 1.18, 0.81 and $1.97 \%$, respectively ${ }^{25}$, all of which were considerably lower than in our study. Butyric acid is a potent inhibitor of cancer cell proliferation, whereas it is also responsible for the rancidity of butter resulting from lipolysis ${ }^{2,33}$. Gun and Simsek ${ }^{2}$ further stated that caproic acid, caprylic acid and capric acid are responsible for problems such as sharp pepper and soapy tastes.

From the current study, the mean monounsaturated and polyunsaturated fatty acid contents of butter samples were
23.12 and $1.62 \%$, respectively and the most abundant monounsaturated fatty acid was oleic acid (C18:1 cis) $(20.79 \%)$. A similar result was reported for yayik butter by Sagdic et al. ${ }^{25}$. Gun and Simsek ${ }^{2}$ reported an oleic acid value of $22.68 \%$ for Karinyagi (traditional butter), which was higher than our figure. Oleic acid is a convenient baseline fatty acid for comparison purposes and assuming it to be neutral puts the effects of other fatty acids into perspective ${ }^{31}$.

Humans do not have the enzymatic capacity to synthesize polyunsaturated fatty acids, so they must be consumed in the $\operatorname{diet}^{2}$. Linoleic acid (C18:2 cis) and linolenic acid (C18:3 cis), which are essential fatty acids, were 0.35 and $0.43 \%$, respectively. Sagdic et al. ${ }^{25}$ stated that the linoleic acid and linolenic acid proportions in their butter samples were 0.16 and $1.18 \%$, respectively, which vary markedly from our results. Furthermore, the mean trans-unsaturated fatty acid (TUFA) (\%) contents of butter samples were minimal; the amount of elaidic acid (C18:1 trans) was $0.45 \%$ and linolelaidic acid (C18:2 trans) was $0.39 \%$. trans-Unsaturated fatty acids are important because they increase the low-density-lipoprotein (LDL) cholesterol (harmful cholesterol) level and decrease the high-densitylipoprotein (HDL) cholesterol (beneficial cholesterol) level ${ }^{34}$.

Short chain fatty acid (SCFA) [except butyric acid (C4:0) and capric acid (C10:0)] and medium chain fatty acid (MCFA) [including tridecanoic acid (C13:0), myristoleic acid (C14:1) and pentadecanoic acid (C15:0)] levels were higher overall in butter produced in the West Black sea region than the other regions $(p<0.05)$. In that region, cows are fed silage and cereal-rich rations indoors, whereas in the other regions, the cows are fed fodder during the winter season and graze during the summer season. Especially in the East Black sea region, dairy cows have access to grassy meadows for long periods of the year.
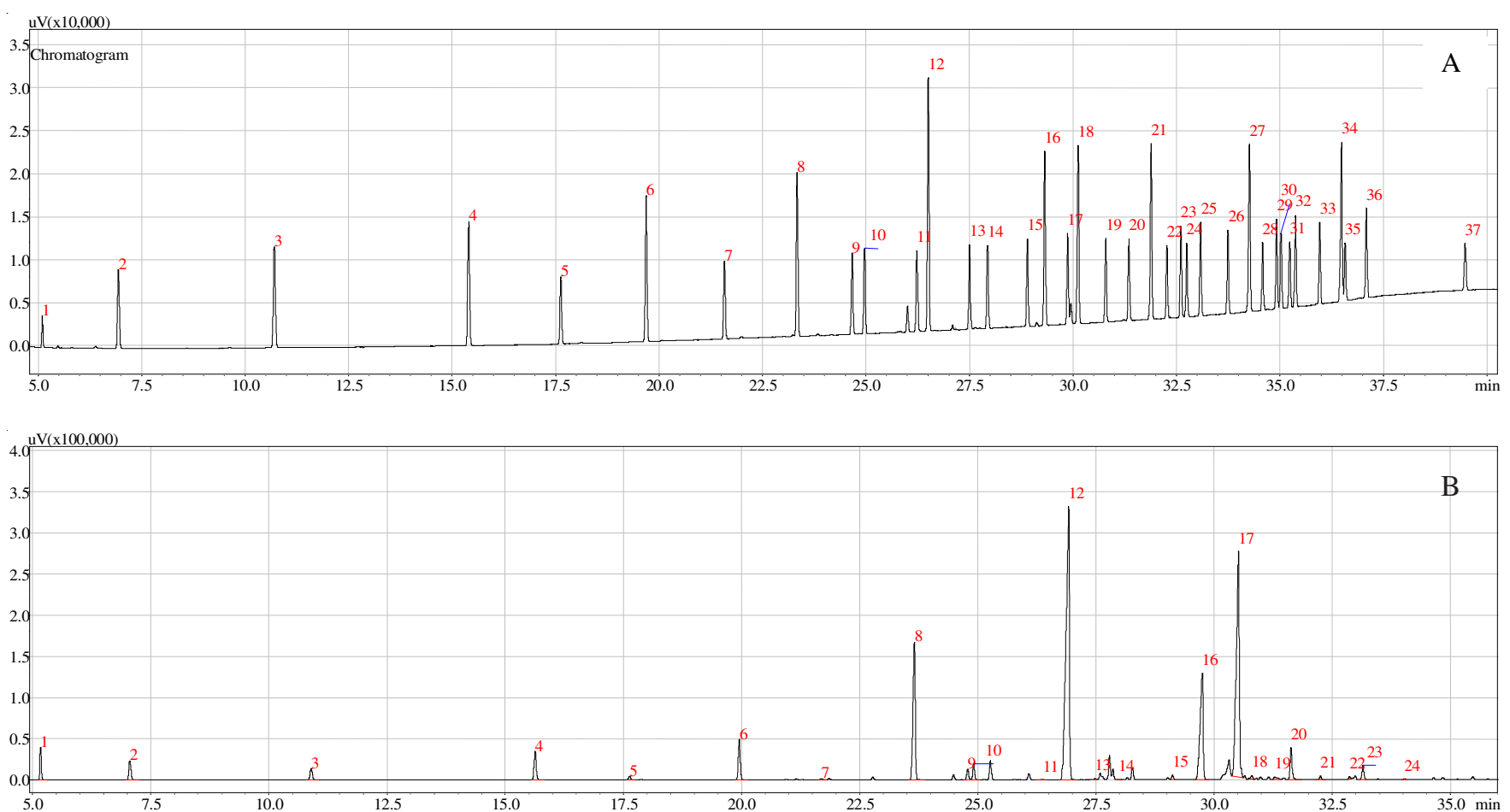

Fig. 1. GC chromatograms of fatty acids obtained from (A) standards and (B) butter samples $\left({ }^{1} \mathrm{C} 4: 0 ;{ }^{2} \mathrm{C} 6: 0 ;{ }^{3} \mathrm{C} 8: 0 ;{ }^{4} \mathrm{C} 10: 0 ;{ }^{5} \mathrm{C} 11: 0 ;{ }^{6} \mathrm{C} 12: 0 ;{ }^{7} \mathrm{C} 13: 0 ;{ }^{8} \mathrm{C} 14: 0\right.$; ${ }^{9} \mathrm{C} 14: 1 ;{ }^{10} \mathrm{C} 15: 0 ;{ }^{11} \mathrm{C} 15: 1 ;{ }^{12} \mathrm{C} 16: 0 ;{ }^{13} \mathrm{C} 16: 1 ;{ }^{14} \mathrm{C} 17: 0 ;{ }^{15} \mathrm{C} 17: 1 ;{ }^{16} \mathrm{C} 18: 0 ;{ }^{17} \mathrm{C} 18: 1$ trans $;{ }^{18} \mathrm{C} 18: 1$ cis $;{ }^{19} \mathrm{C} 18: 2$ trans $;{ }^{20} \mathrm{C} 18: 2$ cis; ${ }^{21} \mathrm{C} 20: 0 ;{ }^{22} \mathrm{C} 18: 3(\gamma) ;$ ${ }^{23} \mathrm{C} 20: 1 ;{ }^{24} \mathrm{C} 18: 3 ;{ }^{25} \mathrm{C} 21: 0 ;{ }^{26} \mathrm{C} 20: 2 ;{ }^{27} \mathrm{C} 22: 0 ;{ }^{28} \mathrm{C} 20: 3$ (n-6) cis; ${ }^{29} \mathrm{C} 22: 1 ;{ }^{30} \mathrm{C} 20: 3$ (n-3) cis; ${ }^{31} \mathrm{C} 20: 4 ;{ }^{32} \mathrm{C} 23: 0 ;{ }^{33} \mathrm{C} 22: 2$ cis; ${ }^{34} \mathrm{C} 24: 0 ;{ }^{35} \mathrm{C} 20: 5$ cis; ${ }^{36} \mathrm{C} 24: 1$ and ${ }^{37} \mathrm{C} 22: 6$ cis $)$ 


\begin{tabular}{|c|c|c|c|c|c|c|}
\hline \multirow{3}{*}{ FA $(\%)$} & \multicolumn{5}{|c|}{$\begin{array}{l}\text { TABLE-3 } \\
\text { FATTY ACID COMPOSITION OF BUTTER SAMPLES COLLECTED FROM THE EAST, MIDDLE AND } \\
\text { WEST BLACK SEA REGIONS OF TURKEY IN OCTOBER-NOVEMBER } 2009 \text { AND MAY-JUNE } 2010\end{array}$} & \multirow{3}{*}{ Average } \\
\hline & \multicolumn{3}{|c|}{ Region* } & \multicolumn{2}{|c|}{ Period** } & \\
\hline & East & Middle & West & First & Second & \\
\hline $\mathrm{C} 4: 0$ & $1.12 \pm 0.57^{\mathrm{a}}$ & $2 \pm 0.41^{\mathrm{a}}$ & $2.36 \pm 0.37^{\mathrm{a}}$ & $2.23 \pm 0.49^{\mathrm{A}}$ & $2.09 \pm 0.45^{\mathrm{A}}$ & $2.16 \pm 0.47$ \\
\hline C6:0 & $1.99 \pm 0.39^{a b}$ & $1.9 \pm 0.32^{\mathrm{bc}}$ & $2.24 \pm 0.31^{\mathrm{a}}$ & $2.03 \pm 0.44^{\mathrm{A}}$ & $2.06 \pm 0.29^{\mathrm{A}}$ & $2.04 \pm 0.36$ \\
\hline $\mathrm{C} 8: 0$ & $1.31 \pm 0.32^{\mathrm{bc}}$ & $1.34 \pm 0.16^{\mathrm{ab}}$ & $1.55 \pm 0.15^{\mathrm{a}}$ & $1.43 \pm 0.23^{\mathrm{A}}$ & $1.37 \pm 0.27^{\mathrm{A}}$ & $1.4 \pm 0.24$ \\
\hline C10:0 & $2.94 \pm 0.72^{\mathrm{a}}$ & $2.98 \pm 0.51^{\mathrm{a}}$ & $3.34 \pm 0.36^{\mathrm{a}}$ & $3.09 \pm 0.52^{\mathrm{A}}$ & $3.19 \pm 0.61^{\mathrm{A}}$ & $3.14 \pm 0.56$ \\
\hline C11:0 & $0.34 \pm 0.1^{\mathrm{b}}$ & $0.32 \pm 0.08^{b}$ & $0.4 \pm 0.06^{\mathrm{a}}$ & $0.37 \pm 0.09^{\mathrm{A}}$ & $0.33 \pm 0.08^{\mathrm{A}}$ & $0.35 \pm 0.09$ \\
\hline C12:0 & $4.2 \pm 0.79^{\mathrm{bc}}$ & $4.92 \pm 0.84^{\mathrm{a}}$ & $4.46 \pm 0.43^{\mathrm{ab}}$ & $4.48 \pm 0.81^{\mathrm{A}}$ & $4.58 \pm 0.69^{\mathrm{A}}$ & $4.53 \pm 0.75$ \\
\hline C13:0 & $0.1 \pm 0.03^{b}$ & $0.1 \pm 0.02^{\mathrm{b}}$ & $0.13 \pm 0.02^{\mathrm{a}}$ & $0.12 \pm 0.03^{\mathrm{A}}$ & $0.1 \pm 0.02^{\mathrm{A}}$ & $0.11 \pm 0.3$ \\
\hline $\mathrm{C} 14: 0$ & $12.7 \pm 0.86^{\mathrm{a}}$ & $12.79 \pm 1.29^{\mathrm{a}}$ & $12.63 \pm 0.92^{\mathrm{a}}$ & $12.64 \pm 0.82^{\mathrm{A}}$ & $12.77 \pm 1.19^{\mathrm{A}}$ & $12.71 \pm 1.01$ \\
\hline $\mathrm{C} 14: 1$ & $0.87 \pm 0.35^{\mathrm{b}}$ & $0.84 \pm 0.23^{b}$ & $1.11 \pm 0.16^{\mathrm{a}}$ & $0.98 \pm 0.24^{\mathrm{A}}$ & $0.89 \pm 0.32^{\mathrm{A}}$ & $0.94 \pm 0.28$ \\
\hline C15:0 & $1.18 \pm 0.36^{\mathrm{b}}$ & $1.21 \pm 0.45^{\mathrm{b}}$ & $1.64 \pm 0.29^{\mathrm{a}}$ & $1.46 \pm 0.34^{\mathrm{A}}$ & $1.21 \pm 0.44^{\mathrm{A}}$ & $1.34 \pm 0.42$ \\
\hline $\mathrm{C} 15: 1$ cis & $0.04 \pm 0.02^{\mathrm{b}}$ & $0.35 \pm 0.13^{\mathrm{a}}$ & $0.28 \pm 0.08^{\mathrm{a}}$ & $0.23 \pm 0.17^{\mathrm{A}}$ & $0.21 \pm 0.16^{\mathrm{A}}$ & $0.22 \pm 0.16$ \\
\hline C16:0 & $32.24 \pm 1.91^{\mathrm{a}}$ & $32.83 \pm 1.55^{\mathrm{a}}$ & $31.39 \pm 1.97^{\mathrm{a}}$ & $31.77 \pm 1.91^{\mathrm{A}}$ & $32.53 \pm 1.78^{\mathrm{A}}$ & $32.15 \pm 1.85$ \\
\hline C16:1 & $0.35 \pm 0.25^{\mathrm{a}}$ & $0.39 \pm 0.2^{\mathrm{a}}$ & $0.48 \pm 0.3^{\mathrm{a}}$ & $0.21 \pm 0.13^{\mathrm{B}}$ & $0.6 \pm 0.19^{\mathrm{A}}$ & $0.4 \pm 0.25$ \\
\hline $\mathrm{C} 17: 0$ & $0.07 \pm 0.05^{\mathrm{a}}$ & $0.05 \pm 0.02^{\mathrm{a}}$ & $0.06 \pm 0.01^{\mathrm{a}}$ & $0.05 \pm 0.01^{\mathrm{A}}$ & $0.07 \pm 0.04^{\mathrm{A}}$ & $0.06 \pm 0.03$ \\
\hline $\mathrm{C} 17: 1$ & $0.22 \pm 0.06^{\mathrm{a}}$ & $0.23 \pm 0.09^{\mathrm{a}}$ & $0.27 \pm 0.04^{\mathrm{a}}$ & $0.24 \pm 0.05^{\mathrm{A}}$ & $0.25 \pm 0.08^{\mathrm{A}}$ & $0.24 \pm 0.06$ \\
\hline C18:0 & $12.41 \pm 2.05^{\mathrm{a}}$ & $11.88 \pm 1.26^{\mathrm{a}}$ & $12.04 \pm 1.79^{\mathrm{a}}$ & $12.91 \pm 1.44^{\mathrm{A}}$ & $11.31 \pm 1.56^{\mathrm{B}}$ & $12.11 \pm 1.68$ \\
\hline C18:1 trans & $0.46 \pm 0.11^{\mathrm{a}}$ & $0.4 \pm 0.1^{\mathrm{a}}$ & $0.49 \pm 0.17^{\mathrm{a}}$ & $0.49 \pm 0.1^{\mathrm{A}}$ & $0.41 \pm 0.15^{\mathrm{A}}$ & $0.45 \pm 0.13$ \\
\hline $\mathrm{C} 18: 1 \mathrm{cis}$ & $21.36 \pm 2.09^{\mathrm{a}}$ & $20.63 \pm 1.85^{\mathrm{a}}$ & $20.4 \pm 1.26^{\mathrm{a}}$ & $20.25 \pm 1.22^{\mathrm{B}}$ & $21.34 \pm 2.06^{\mathrm{A}}$ & $20.79 \pm 1.75$ \\
\hline $\mathrm{C} 18: 2$ trans & $0.38 \pm 0.1^{\mathrm{a}}$ & $0.35 \pm 0.13^{\mathrm{a}}$ & $0.42 \pm 0.11^{\mathrm{a}}$ & $0.39 \pm 0.12^{\mathrm{A}}$ & $0.38 \pm 0.11^{\mathrm{A}}$ & $0.39 \pm 0.12$ \\
\hline $\mathrm{C} 18: 2$ cis & $0.36 \pm 0.18^{\mathrm{a}}$ & $0.33 \pm 0.15^{\mathrm{a}}$ & $0.36 \pm 0.18^{\mathrm{a}}$ & $0.39 \pm 0.16^{\mathrm{A}}$ & $0.31 \pm 0.16^{\mathrm{B}}$ & $0.35 \pm 0.16$ \\
\hline C20:0 & $0.28 \pm 0.12^{\mathrm{a}}$ & $0.33 \pm 0.2^{\mathrm{a}}$ & $0.29 \pm 0.11^{\mathrm{a}}$ & $0.3 \pm 0.17^{\mathrm{A}}$ & $0.31 \pm 0.16^{\mathrm{A}}$ & $0.3 \pm 0.14$ \\
\hline $\mathrm{C} 20: 1 \mathrm{cis}$ & $0.06 \pm 0.02^{\mathrm{a}}$ & $0.05 \pm 0.01^{\mathrm{a}}$ & $0.06 \pm 0.02^{\mathrm{a}}$ & $0.06 \pm 0.02^{\mathrm{A}}$ & $0.05 \pm 0.02^{\mathrm{A}}$ & $0.05 \pm 0.02$ \\
\hline C18:3 & $0.44 \pm 0.09^{\mathrm{a}}$ & $0.44 \pm 0.01^{\mathrm{a}}$ & $0.39 \pm 0.03^{\mathrm{a}}$ & $0.45 \pm 0.09^{\mathrm{A}}$ & $0.39 \pm 0.06^{\mathrm{A}}$ & $0.43 \pm 0.08$ \\
\hline $\mathrm{C} 21: 0$ & $1.19 \pm 0.41^{\mathrm{a}}$ & $1.16 \pm 0.44^{\mathrm{a}}$ & $1.47 \pm 0.47^{\mathrm{a}}$ & $1.29 \pm 0.4^{\mathrm{A}}$ & $1.15 \pm 0.47^{\mathrm{A}}$ & $1.27 \pm 0.45$ \\
\hline Others & $1.91 \pm 0.44^{\mathrm{a}}$ & $1.69 \pm 0.64^{\mathrm{ab}}$ & $1.31 \pm 0.46^{\mathrm{bc}}$ & $1.59 \pm 0.49^{\mathrm{A}}$ & $1.68 \pm 0.64^{\mathrm{A}}$ & $1.64 \pm 0.56$ \\
\hline SCFA & $12.9 \pm 2.43^{\mathrm{bc}}$ & $13.47 \pm 1.05^{\mathrm{ab}}$ & $14.36 \pm 0.75^{\mathrm{a}}$ & $13.63 \pm 1.83^{\mathrm{A}}$ & $13.52 \pm 1.51^{\mathrm{A}}$ & $13.57 \pm 1.65$ \\
\hline MCFA & $47.48 \pm 1.71^{\mathrm{a}}$ & $48.51 \pm 1.83^{\mathrm{a}}$ & $47.65 \pm 2.19^{\mathrm{a}}$ & $47.42 \pm 1.52^{\mathrm{A}}$ & $48.35 \pm 2.19^{\mathrm{A}}$ & $47.88 \pm 1.91$ \\
\hline LCFA & $39.61 \pm 2.46^{\mathrm{a}}$ & $38.01 \pm 2.26^{a}$ & $37.99 \pm 2.08^{\mathrm{a}}$ & $38.96 \pm 1.65^{\mathrm{A}}$ & $38.13 \pm 2.85^{\mathrm{A}}$ & $38.54 \pm 2.33$ \\
\hline SFA & $73.06 \pm 1.66^{\mathrm{a}}$ & $73.82 \pm 2.13^{\mathrm{a}}$ & $74.01 \pm 1.32^{\mathrm{a}}$ & $74.27 \pm 1.35^{\mathrm{A}}$ & $72.99 \pm 1.85^{\mathrm{B}}$ & $73.63 \pm 1.72$ \\
\hline MUFA & $23.37 \pm 1.77^{\mathrm{a}}$ & $22.88 \pm 1.63^{\mathrm{a}}$ & $23.08 \pm 1.38^{\mathrm{a}}$ & $22.46 \pm 1.17^{\mathrm{B}}$ & $23.77 \pm 1.65^{\mathrm{A}}$ & $23.12 \pm 1.56$ \\
\hline PUFA & $1.66 \pm 0.31^{\mathrm{a}}$ & $1.59 \pm 0.32^{\mathrm{a}}$ & $1.6 \pm 0.28^{\mathrm{a}}$ & $1.67 \pm 0.33^{\mathrm{A}}$ & $1.56 \pm 0.25^{\mathrm{A}}$ & $1.62 \pm 0.29$ \\
\hline
\end{tabular}

FA: Fatty acids; SCFA: Short chain fatty acids; MCFA: Medium chain fatty acids; LCFA: Long chain fatty acids; SFA: Saturated fatty acids; MUFA: Monounsaturated fatty acids; PUFA: Polyunsaturated fatty acids. Values are expressed as mean \pm standard deviation. ${ }^{*}$ a-c and ${ }^{* * *}$ A-B: means with different letters in a row (ie within the same category) are significantly different $(p<0.05)$.

Palmitoleic acid, stearic acid and oleic acid levels in our butter samples were influenced by seasonal variations $(p<$ 0.05). Palmitoleic acid and oleic acid levels were higher in May-June (second period) than in October-November. Generally, cows graze in pastures (herbaceous plants, including grass) during spring and summer and these plants are rich in unsaturated fatty $\operatorname{acids}^{35}$. The significantly higher levels $(p<$ $0.05)$ of stearic acid in the first period (12.91\%) compared to the second period $(11.31 \%)$ are surprising because the presence of stearic acid in milk fats mainly results from the movement of unsaturated $\mathrm{C}_{18}$ fatty acids in feedstuffs (C18-rich grass) to the udder ${ }^{35}$. Overall, butter from summer milk contained more unsaturated fatty acids and long chain fatty acids and less short and medium chain saturated fatty acids, than butters from winter milk. These observations are confirmed by Ledoux et al. ${ }^{32}$ and Wolf et al. ${ }^{36}$.

\section{Conclusion}

At present, there are no recognized standards for the chemical contents of butter in Turkey. As a result, it is not possible to state that the samples analyzed in the current study were fit for human consumption. However, most of the samples in present study did not comply with the Turkish Butter Standards ${ }^{3}$ and Turkish Food Codex ${ }^{18}$ criteria for acceptable content of total solids, fats and non-fat dry matter. In the broader picture, the season influenced the saturated and monounsaturated fatty acid composition of the various butters. Fatty acid profiling revealed that palmitic acid was the predominant saturated fatty acid and that oleic acid was the major monounsaturated fatty acid. Myristic acid and stearic acid were also found in high quantities.

Overall, the results of our microbiological analyses indicate that poor hygiene standards exist during manufacturing, packaging and marketing of butter in the Black Sea Region of Turkey. The presence of coliform bacteria and E. coli, together with the high total microorganism counts, suggests that there is inadequate heat treatment of milk and cream and/or low hygiene standards in processing and packaging. To improve the microbiological profiles of butter and hence make it a safer food product, the milk or cream must be adequately pasteurized and the latest techniques, equipment and practices employed throughout the production process. 


\section{ACKNOWLEDGEMENTS}

The authors are grateful to the Ondokuz Mayis University Research Foundation (PYO.MUH.1901.09.005) for supporting this research and Gregory T. Sullivan of the School of Foreign Languages at the same university for editing the English in an earlier version of this manuscript.

\section{REFERENCES}

1. O. Sagdic, M. Arici and O. Simsek, Food Microbiol., 19, 303 (2002).

2. I. Gun and B. Simsek, Food Nutr. Sci., 2, 402 (2011).

3. Butter, Turkish Standard 1331, Ankara, Turkey (1995).

4. I. Altun, S. Andic, Y. Tuncturk, A. Cecen and O. Findik, Kafkas Univ. Vet. Fak. Derg., 17, 645 (2011) (in Turkish).

5. S. Gonenc and H. Tanrivermis, Int. J. Dairy Technol., 61, 3 (2008).

6. Butter-Determination of Water, Solids-non-fat and Fat Contents on the Same Test Portion, International Standard 80. Brussels: International Dairy Federation (1977)

7. Y. Ardo and A. Polychroniadou, Laboratory Manual for Chemical Analysis of Cheese. COST 95, Luxemburg. Luxembourg: Office for Official Publications of the European Communities (1999).

8. R.L. Bradley, E. Arnold, D.M. Barbano, R.G. Semerad, D.E. Smith and B.K. Vines, In ed.: R.T. Marshall, Chemical and Physical Methods, In Standard Methods for the Examination of Dairy Products; American Public Health Association: Washington DC, pp. 433-529 (1992).

9. Association of Official Analytical Chemists, Official Methods of Analysis, Association of Official Analytical Chemists, Washington, DC (1992).

10. O. Samet-Bali, M.A. Ayadi and H. Attia, Food Sci. Technol., 42, 899 (2009).

11. J.F. Frank, G.L. Christen and L.B. Bullerman, In ed.: R.T. Marshall, Tests for Groups of Microorganisms, Standard Methods for the Examination of Dairy Products, American Public Health Association, edn. 16 (1992).

12. S. McBrearty, R.P. Ross, G.F. Fitzgerald, J.K. Collins, J.M. Wallace and C. Stanaton, Int. Dairy J., 11, 599 (2001).

13. International Standard ISO 16649-2: Microbiology of Food and Animal Feeding Stuffs "Horizontal method for the enumeration of pre- sumptive Escherichia coli; Part 2: Colony-count technique at $44{ }^{\circ} \mathrm{C}$ using 5-bromo-4-chloro-3-indolyl- $\beta$-D-glucoronic acid (1999).

14. Gida ve hayvan yemlerinin mikrobiyolojisi-Koagulaz-pozitif stafilakoklarin (Staphylococcus aureus ve diger türler) sayimi için yatay metot-Bölüm 1: Baird-Parker Agar besiyeri kullanilarak, Türk Standartlari Enstitüsü, TS 6582-1 EN ISO 6888-1, p 14, Ankara (2001) (in Turkish).

15. G. Mucchetti, R. Ghiglietti, F. Locci, S. Francolino, B. Bonvini, M.C. Remagni, M. Zago, R. Iezzi and D. Carminati, Dairy Sci. Technol., 89, 419 (2009).

16. M. Gobbetti, B. Folkertsma, P.F. Fox, A. Corsetti, E. Smacchi, M.D. Angelis, J. Rossi, K. Kilcawley and M. Cortini, Int. Dairy J., 9, 763 (1999).

17. G. Zeppa, M. Giordan, V. Gerbi and M. Arlorio, Lait, 83, 167 (2003).

18. Türk Gida Kodeksi Tereyagi, Diger Süt Yagi Esasli Sürülebilir Ürünler ve Sadeyag Tebligi. Teblig No: 2005/19. Basbakanlik Basimevi, Ankara (2005) (in Turkish).

19. K. Mourad and K. Nour-Eddine, Grasas Aceites, 57, 198 (2006).

20. H. Rohm, M. Strobl and D. Jaros, Z. Lebensm. Unters. Forsch. A, 205, 108 (1997)

21. Türk Gida Kodeksi Mikrobiyolojik Kriterler Tebligi. Teblig No: 2009/ 6. Basbakanlik Basimevi, Ankara (Turkish), (2009).

22. N. Karagozlu and B. Ergonul, J. Verbr. Lebensm., 3, 376 (2008).

23. R. Gokce, Y. Aslanalp and E.N. Herken, Grasas Aceites, 61, 121 (2010).

24. I. Gun, SDU, J. Grad. School Nat. Appl. Sci., 7, 55 (2003).

25. O. Sagdic, M. Donmez and M. Demirci, Food Control, 15, 485 (2004).

26. A.D. Altalhi and S.A. Hassan, Food Control, 20, 913 (2009).

27. G. Giraffa, Fems. Microbiol. Rev., 26, 163 (2002).

28. G. Urbach, Int. Dairy J., 5, 877 (1995).

29. M.R. Adams and L. Nicolaides, Food Control, 8, 227 (1997).

30. W.H. Holzapfel, Int. J. Food Microbiol., 75, 197 (2002).

31. S.M. Grundy, Am. J. Clin. Nutr., 66, 988 (1997).

32. M. Ledoux, F.M. Chardigny, M. Darbois, Y. Soustre, J.L. Sebedio and L. Laloux, J. Food Compos. Anal., 18, 409 (2005).

33. P.W. Parodi, J. Nutr., 127, 1055 (1997).

34. A.M. Salter, Clin. Sci., 88, 373 (1995).

35. G. Jahreis, J. Fritsche and H. Steinhart, Fett/Lipid, 98, 356 (1996).

36. R.L. Wolff, C.C. Bayard and R.J. Fabien, J. Am. Oil. Chem. Soc., 75, 1471 (1995). 